\title{
The research of language communication education strategy: The Belt and Road background
}

\author{
Jingjing Wang ${ }^{1, a}$ \\ ${ }^{1}$ School of music and dance, Qujing Nornal University, Yunnan, China, 655011 \\ awangj815@163.com
}

\begin{abstract}
Keywords: spolicy communication, foreign language, key words, five links
\end{abstract}
Abstract. "Silk Road Economic Belt" and twenty-first century "maritime Silk Road" referred to as "The Belt and Road". "Belt and Road Initiative" as a long-term strategic decision in economic exchanges and interaction along the surrounding countries, plays a long-term role. "Belt and Road Initiative along many neighboring countries, a total of 65 countries, the population reached 4 billion 400 million, occupying $60 \%$ of the total population of the world, therefore, The Belt and Road neighboring countries to carry out mutual aid, cooperation and win-win opportunities and broad prospects. "Belt and Road Initiative" advocated by the "five links" policy, communication facilities Unicom, trade flow, the circulation of money and the people connected to achieve this five way cannot do without language development, language service follow up show "The Belt and Road" language education development strategy provides an opportunity with language education strategy the opportunities and challenges in the "The Belt and Road" platform, establish and perfect the corresponding language education policy is very important, this paper reflects on the Chinese language education strategy based on "The Belt and Road" background, focuses on the two aspects of Chinese foreign policy and "critical language" policy, and put forward relevant proposals. To policy formulation.

In September 2013 and October, "The belt and road" strategy are the president Xi Jinping proposed during a visit to the Central Asian and Southeast Asian countries, along the countries have a positive response. The ancient "Silk Road" not only assumed the important task of commercial prosperity in antediluvian times, but also provided a channel for the world's cultural exchanges. The Silk Road brought the Chinese goods into the world and the Chinese culture to the world. So far, the The Belt and Road again ignited the brilliance of the silk, we never forget the role of the Silk Road in the cultural transmission, a road has strengthened this effect, the countries along the trade with each other, culture communication, language communication, the China culture once again to the world, opened to international the channel, again to achieve a win-win situation.

"The core The Belt and Road": unity and mutual trust, equality, tolerance and mutual learning, cooperation and win-win, through Central Asia, South Asia, Southeast Asia, West Asia and other regions, with Asia Pacific and Europe's two largest economic circle, build a continuous prosperity and win-win road. "Belt and Road Initiative" strategy is adhesive each country along, strengthen the integration of various countries, especially in the field of education, because education is strong, education makes the conflict between the various cultural exchange weakened, personnel training as a priority among priorities along the national policy, for providing support for the economic development of talent culture. "The Belt and Road" strategy to promote along the national educational policy exchange, provide policy guidance and support for educational cooperation, have to carry out pragmatic cooperation in multi-level and multi field to the school, realize the sharing of high-quality educational resources, and the depth of cooperation and cooperative communication, active close joint development situation.

\section{1."The Belt and Road" the importance of language education}

"This the belt and road" strategy to enhance exchanges and cooperation with China along with various countries and regions, and as a bridge between the natural language has become a key factor. "Belt and Road Initiative along includes 65 countries and regions (including [1] Mongolia, the 10 ASEAN countries in East Asia and West Asia, South Asia, Central Asia's 1885 country, 7 CIS countries and 16 central and Eastern European countries) these countries a total of 53 official 
languages of the 53 languages are divided into nine. To promote the belt and road strategic premise to realize the five ways are, we must realize the "language exchange", language as a communication tool is based on five links, is the bridge and link all connected cooperation.

Because of the role of language bridge and link, "The belt and road" strategy are bound to language education into the strategic plan, in order to achieve barrier free communication between countries along. Countries should strengthen language education mechanism, which can complete the exchange coordination mechanism as soon as possible, all countries should jointly develop curriculum, thus improving the smooth flow of communication, and the course as soon as possible into the national education system. Give full play to the advantages of talents training plan and each language in the foreign language school, to speed up the progress of the cultivation of language talents; to support more social forces to help Confucius college and the Confucius classroom building, enhance the Chinese teachers and Chinese volunteer teachers team construction, to meet along the national demand for Chinese learning.

Language as a booster in The Belt and Road is the backbone, some people say that the people is the foundation of society, so the link language is popular in collusion, exchanges can only make people connected, exchanges can only make people's basic needs are expressed. Mandela [2] once said: "to understand the language of communication in mind; with language, accent, engraved in my heart." Language can open a country, is to enter the country's stepping stone, language to promote cultural transmission along the way, as a carrier of cultural transmission, leading Chinese culture to go out, to the world. Cultural exchange is the first language communication, cultural exchanges in the world to extend the world cannot be separated from the carrying of language. Language is the foundation of the country to the world governance, international dialogue, economic and trade. Language coverage along the way will have a profound impact on global governance. Do Chinese, speak good Chinese language, speak good Chinese civilization, language and cultural exchanges in the way we go15, in this platform, we communicate with each other is two, are the implementation of the exchange, there is a feedback communication. Two-way communication, civilized mutual learning. On the one hand, we have to learn the language and customs of each country, national culture. On the other hand, we also need to push the Chinese Belt and Road Initiative along the countries around the world, to promote the spread of Chinese in the international, lay the foundation for the spread of Chinese culture, as Chinese civilization, China economy to the world contribute, set foundation for the long-term development of the Belt and Road Initiative.

\section{Teaching Chinese as a foreign language to promote the spread of Chinese culture}

With the development of Chinese, more and more people learning Chinese around the world, according to statistics the number of Chinese learning has reached more than 100 million, while learning Chinese country is up to more than and 100, of which 2500 universities have to learn the Chinese language courses, Chinese language has been out of the country to the world, some countries even in the primary school opened Chinese courses thus, Chinese influence in the world. Confucius Institute in China has become more and more popular around the world. And the Confucius Institute currently has more than and 300. There The Belt and Road and rise are to promote development and dissemination of Chinese. Belt and Road Initiative is a new platform in this new platform. We should consider the new combination of Chinese development, seeking innovation and cater to the needs of. The advance of the Chinese language is quickly is not mature, have a lot of problems during this period, first, there is no specific textbook compiling, the teaching method is single and boring, no conditions. Second, the teaching of Chinese as a foreign language is weak, the teachers"s ability is uneven, the lack of more standardized training and guidance, leading to "false teachers" is also common. Foreign language teaching is not only teaching, especially the culture and civilization communication channels, is also our country in the foreign people in the eyes of the miniature, so foreign language can not be sloppy, we should be strict, is a representative of the national image, is the representative of the national civilization.

In China, the number of foreign language universities for the statistical range of 60 [3], compared with Russia more than 100. And the more than and 100 is mainly concentrated in the Moscow language university and the University of St Petersburg, the language used in Britain will have as 
many as 150 kinds, the foreign language training plan also further strengthened, is expected to more than 200 kinds of comparison, language education in China is mainly a single language, the resulting lack of talents, which in Belt and Road Initiative strategy will hinder the development of the communication of culture, the foot step of our cultural exchanges will be hindered, so use this platform to adjust the strategy of language education, the positive development of language education construction.

In this regard, it should be done: first, to write a simple and easy to complete the Chinese language teaching materials, improve its general applicability and pertinence, and to join a certain cultural characteristics. Second, improve teaching methods, to distinguish between students of different cultural backgrounds, different ages, for its teaching method, to carry out special targeted teaching, fully mobilize students' enthusiasm and participation. Third, increase the capital into education, strengthen the construction of teaching team, the establishment of comprehensive quality strong professional ability, good team, urge teachers staff to strengthen their cultural accomplishment constantly, to understand Chinese culture, and actively responsible propaganda and carry forward the Chinese culture in the teaching of Chinese at the same time.

"The Belt and Road" countries along the unique local customs and practices, educational background, economic foundation. No matter which country we should be based on equality and mutual benefit, mutual solidarity and tolerance, voluntarily accept the [4], enhance national cultural understanding, influence others to use the most simple language, the most sincere way, so that China carry forward culture going out. In addition, the spread of Chinese language also need social and business promotion, relying solely on the government's strength is not enough, social organizations, enterprises should play its resources, reasonable control of various educational institutions from all walks of life to improve the language learning and language services. To create a national people can understand, easy to accept, the representative of the artistic products to meet the needs of various enterprises, industries, schools, communities and other Chinese culture. Through the Confucius Institute to provide educational institutions such as consulting, in various industries, various fields of communication strategies in language education, promote the progress of language communication and the breadth, and strive for the China culture to the world, not only to let foreigners learn more, should let them know, understand and experience the broad and profound culture Chinese.

\section{Other countries come into the language}

In the "The Belt and Road" background, English as the most widely used international language, the main language is among the most countries. In The Belt and Road cultural exchange between countries, English is the dominant, therefore, it is particularly important to English education, by carrying out targeted application of English education courses, practical courses strong, effectively cultivate students' application ability of English and post related, for the construction of socialist modernization and the construction of "The Belt and Road" profound.

"The Belt and Road" relates to the national language and national official language is more than and 50, covering most areas in South Asia and West Asia, [5], in which each country and regional ethnic groups or tribes with independent language, this part of the autonomous language added about two hundred. English, Chinese, Malay and Tamil are official languages in Singapore. Only the national language of Indonesia is more than and 200. The main languages are English, followed by Russian and Arabic, Singapore, Brunei, Vietnam and Malaysia. Although English is the most widely used language in the world, but in these countries, if the country will use the native language or tribal languages, then the communication will be smooth, misunderstandings will be reduced, many things will be easier,

"Obviously the international market effect The Belt and Road" cause, which also led us to cultivate "critical language talent idea, through learning foreign languages, culture specific talent culture, further long-term exploration countries customs, local people perceive the idea of smooth integration into the national culture, so as to" The Belt and Road "the economic and cultural communication to pave the way. For the smooth implementation of the "five lines" help, therefore, the positive development of language education strategies for the "key language" education to develop strategies, field research, develop strategies, supervise the implementation of relevant laws 
and regulations. Secondly, the national education department should increase the reform of foreign language teaching, and enhance the quality of foreign language teaching in colleges and universities. And the key language talents of all walks of life, and let these people do, play their respective roles in their respective industries, the combination of language and culture and culture industry, and contribute to the spread of culture in the way of language education, language talents key aims to cultivate special language education personnel, is a comprehensive talent, is an important component of language the spread of education.

\section{Conclusion}

President Xi on the construction of the "The Belt and road" strategy not only promote economic development, but also provides platform support for language education. In China, many universities are actively adjust the foreign language curriculum, in order to support the needs of national belt and Road Initiative "language development. In the aspect of international [7], July 8, 2015, Confucius, the Royal Academy of Kampuchea successfully hosted the Belt and Road Initiative symposium, People's Republic of China Embassy in Kampuchea, ambassador extraordinary and plenipotentiary cloth founding you as a special guest keynote report; September 8, 2015, Thailand Kokukawa Toki University superbly Confucius college professor, Guangxi University business school invited ASEAN Research Institute of Thailand Institute of Chinese Yue Guining held Belt and Road Initiative theme lectures, etc.. To sum up, from domestic to international, everyone from the individual to the group, and development is no longer "The Belt and Road" language education communication contribute to each organization, our patriotic dedication, support the party's policies for the cultural transmission China, language communication a dedication of their own strength, not language education the cause of the spread of Chinese will usher in a new tomorrow.

\section{References:}

[1]Clegg J, Vance M. Special Edition on `Research and practice in the language and communication needs of adolescents in secondary education'Call for Papers[J]. Child Language Teaching \& Therapy, 2008, 24(3):363-364.

[2]Lin H. Establishing an Empirical Link between Computer-Mediated Communication (CMC) and SLA: A Meta-Analysis of the Research.[J]. Language Learning \& Technology, 2014, 18(3):120-147.

[3]Lindsay G. The Collection and Analysis of Data on Children with Speech, Language and Communication Needs: The Challenge to Education and Health Services.[J]. Child Language Teaching and Therapy, 2011, 27(2):135-150.

[4]Warren S F. The Future of Early Communication and Language Intervention.[J]. Topics in Early Childhood Special Education, 2000, 20(1):33-37.

[5]Vance M, Clegg J. Editorial: Research and practice in the language and communication needs of adolescents in secondary education[J]. Child Language Teaching \& Therapy, 2010, 26(2):101-103.

[6]Turnbull J, Prichard J, Halford S, et al. Reconfiguring the emergency and urgent care workforce: mixed methods study of skills and the everyday work of non-clinical call-handlers in the NHS[J]. Journal of Health Services Research \& Policy, 2012, 17(4):233.

[7]Theaker A. Review: Belteke van Ruler, Ana Tkalac Verč ič and Dejan Verč ič (eds), Public Relations Metrics: Research and Evaluation. New York and London: Routledge, 2008. £22.99. 328 pp[J]. European Journal of Communication, 2009, 24(3):362-365. 